\title{
COMPETITION POLICY AND ORGANIZATIONAL FRAGMENTATION IN HEALTH CARE
}

\author{
Thomas (Tim) Greaney*
}

Once upon a time ... and a very good time it was, advocates for marketbased approaches to health policy had a coherent story to tell. Cost and quality would remain suboptimal as long as fee-for-service medicine persisted and the myriad market imperfections that impede efficiency went unchecked. However, things could be righted by adopting principles associated with managed care, together with pursuing sensible antitrust enforcement and government deregulation to clear away the private and regulatory underbrush obstructing market forces. Economic theorists and policy experts agreed that these steps would effectively address information, agency, and moral hazard problems and begin to glue together the pieces of our fragmented delivery system. And, for a while, things seemed to work out as promised. Providers began to reorganize into firms and other integrating arrangements and health insurers adopted financial and contractual measures designed to align provider incentives with consumer needs. Regulators directed policies at removing obstacles to competition and antitrust enforcers sought to encourage efficient consolidation while blocking cartels and provider oligopolies. Spiraling costs leveled off for a while and both payment systems and provider organizations began to adapt to market forces.

But things changed. A powerful backlash against managed care (precipitated in part by insurers' short-sighted and sometimes abusive tactics) gave rise to regulations that undermined some of the methods managed care had used effectively while payors voluntarily withdrew from active involvement in care management. Managed care and the competitionenhancing practices it had begun to spawn-integration and rivalryunraveled. Several important lessons for competition policy emerge from the demise of the managed care era. First, a number of factors deeply embedded in the nation's health care apparatus encouraged resistance to competition. Even during the heyday of antitrust enforcement and market-favoring policies,

\footnotetext{
* Chester A. Myers, Professor of Law and Director, Center for Health Law Studies, Saint Louis University School of Law. This paper was originally presented at the Harvard Law School Petrie-Flom Center for Health Law Policy Conference, "Our Fragmented Health Care System: Problems and Solutions." Thanks to participants for insights and suggestions.
} 
many institutions and organizational structures changed little, as social norms and market imperfections proved to be powerful counterweights to conventional market incentives. In addition, many statutes, judicial decisions, and governmental financing programs operated at cross purposes with the goals of competition policy. Nor are things likely to improve soon. Today's emerging market-oriented paradigm, "consumer directed health care," which requires consumers to shoulder responsibility for making comparisons on the price, intensity, and quality of services they receive, threatens to increase fragmentation and does little to address the underlying imperfections of health care markets.

A central challenge for all health care reform proposals currently being discussed is finding the means to effectively channel market forces given many deeply embedded features of our system and the peculiar economics of health care delivery and financing. This essay traces the path of competition law in health care and explains its chicken-and-egg relationship with provider organizational arrangements. It explores a central puzzle for future health care policy: Why have market forces failed to counteract organizational fragmentation? Answering this question requires an understanding of why competition policy is inexorably linked to the organizational structures of health care providers and payers and how the fragmentation that bedevils those arrangements has undermined its success. The article concludes with a negative assessment of recent "consumer directed" approaches, finding them likely to increase fragmentation and incapable of delivering the benefits of competition.

\section{How COMPETITION PoLICY TRIED to DEAL WiTh FRAGMENTATION AND WHY IT FAILED}

\section{Antitrust Law's Two-Pronged Approach}

Historically, much of what can be broadly classified as "competition policy" in health care is found in the application of antitrust principles to the conduct and structure of provider and payor organizations rather than in any sweeping statutory enactments. Although some landmark legislation, such as the repeal of health planning statutes and adoption of the 1973 HMO law, ${ }^{1}$

1. Health Maintenance Organization Act of 1973, 42 U.S.C. $\S \S 300 \mathrm{e}-300 \mathrm{e}-17$ (2006). The HMO Act established a federal qualifying system that provided seed money for new HMOs, required employers to offer an HMO option if the employer provided traditional indemnity coverage to its employees, and preempted state laws and policies that inhibited HMO formation. 
ERISA, ${ }^{2}$ and other state laws facilitating competitive contracting through preferred provider organizations and in federal and state-funded health programs, ${ }^{3}$ removed some important barriers to the growth of managed care, while the task of dealing with unacceptable practices and problematic market structures was left to antitrust law.

For some thirty years, federal and state antitrust enforcement agencies (the Federal Trade Commission (FTC), the United States Department of Justice (DOJ), and state attorneys general) have employed antitrust law to promote competition in health care. The battle has been fought on two fronts. First, applying standard principles of industrial organization economics, the agencies have devoted enormous resources to challenging cartels, professional restraints, mergers and anticompetitive joint ventures in hospital, physician, pharmaceutical, and managed care sectors. Second, and less widely recognized, the agencies have engaged in extensive quasi-administrative efforts to encourage development of payment methods and organizations conducive to competition and efficiency. The latter, which has taken the form of advisory opinions, consent decrees, speeches, advice to legislatures, and statements of enforcement policy, has engendered controversy. ${ }^{4}$ In litigation, the government's focus sometimes turned to engineering complex, conductoriented settlements rather than seeking structural or criminal remedies. In issuing policy statements or advisory opinions the agencies have not hesitated to stress the desirability of preferred organizational forms, notably fully integrated, risk sharing arrangements. ${ }^{5}$ Antitrust enforcers have also tried to

2. Employee Retirement Income Security Act of 1974 (ERISA), Pub. L. No. 93-406, 88 Stat. 829 (codified as amended at 29 U.S.C. $§ § 1001-1461$ (2006)).

3. See Elizabeth S. Rolph et al., State Laws and Regulations Governing Preferred PROVIDER ORGANIZATIONS 28-29 (1986) (describing early legislative attempts to encourage competition by removing obstacles to competitive contracting).

4. See Thomas E. Kauper, The Justice Department and the Antitrust Laws: Law Enforcer or Regulator?, 35 ANTITRUST BULl. 83 (1990); Thomas L. Greaney, Regulating for Efficiency in Health Care Through the Antitrust Laws, 1995 UTAH L. REV. 465 [hereinafter Greaney, Regulating for Efficiency in Health Care]; E. Thomas Sullivan, The Antitrust Division as a Regulatory Agency: Antitrust Policy in Transition, 64 WASH. U. L.Q. 997 (1986); Jon Leibowitz, Comm'r, Fed. Trade Comm'n, Health Care and the FTC: The Agency as Prosecutor and Policy Wonk, Remarks at the Antitrust in HealthCare Conference of the American Bar Association/American Health Lawyers Association (May 12, 2005), available at http://www.ftc.gov/speeches/leibowitz/050512healthcare.pdf.

5. See, e.g., J. Thomas Rosch, Comm'r, Federal Trade Comm'n, Clinical Integration in Antitrust: Prospects for the Future, Remarks at the Antitrust in Healthcare Conference of the American Bar Association/Amercian Health Lawyers Association (Sept. 27, 2007), available at www.ftc.gov/speeches/ rosch/070917clinic.pdf [hereinafter Rosch, Clinical Integration]. See generally Lawrence Casalino, The Federal Trade Commission, Clinical Integration, and the Organization of Physician Networks, $31 \mathrm{~J}$. HEALTH POL. POL’Y \& L. 569 (2006). 
clear the way for joint ventures in purchasing, sharing information and other forms of cooperation. For example, the joint FTC/DOJ Policy Statements, issued in 1994 in part to bolster support for the Clinton health reforms, provided extensive guidance including "safety zones" that offered assurance that antitrust enforcement would not interfere with restructuring undertaken to respond to the evolving competitive environment. ${ }^{6}$

Taken together, these efforts had a distinctly regulatory flavor, as the guidance provided often extended beyond generalities about enforcement priorities or assessments of the proper construction of precedent. In the case of physician networks, for example, the guidance regularly commended specific contractual arrangements and network operations that were likely to satisfy the agencies' interpretation of antitrust law. ${ }^{7}$ While prescriptive regulation and antitrust enforcement are usually seen as incompatible, in this case they were not. As argued below, the agencies' approach has been driven by an economically sound focus on mitigating market failure and was a necessary ingredient of sound competition policy.

Efforts to limit cartelization and provider monopolies in health care have been a staple of antitrust enforcement for almost thirty years. Following the Supreme Court's landmark decision in Goldfarb v. Virginia State Bar, ${ }^{8}$ the FTC and DOJ embarked on a series of challenges to professional restraints of trade including ethical codes prohibiting advertising, contracting and affiliation with HMOs, and affiliation with alternative care providers. Since then, federal and state enforcers also prosecuted nearly 100 cases involving price fixing cartels, physician boycotts that sought to deter innovative financing plans, block competition from alternative care providers, or organize collective bidding. ${ }^{9}$ Over the years, physician groups and associations have attempted to justify collective action on the basis of preserving professional sovereignty, "leveling the playing field" vis-à-vis insurers, assuring that

6. See Thomas L. Greaney, The Department of Justice/FTC Health Care Policy Statements: A Critique, 8 ANTITRUST 20 (Spring 1994).

7. See Clark C. Havighurst, Are the Antitrust Agencies Overregulating Physician Networks?, 8 LOY. CONSUMER L. REV. 78, 93 (1996) (contending that antitrust enforcers inappropriately favored financial risk sharing); Casalino, supra note 5.

8. Goldfarb v. Va. State Bar, 421 U.S. 773 (1975).

9. See, e.g., Matter of Am. Med. Ass'n, 94 F.T.C. 701 (1979), aff'd as modified, 638 F.2d 443 (2d Cir. 1980), reh'g denied, 456 U.S. 966 (1982); United States v. N.D. Hosp. Ass'n, 640 F. Supp. 1028 (D.N.D. 1986); In re Mich. State Med. Soc'y, 101 F.T.C. 191 (1983). See generally B. FuRROW ET AL., HeAlth LAW § 14-10 (2000); Thomas L. Greaney, Whither Antitrust? The Uncertain Future of Competition Policy in Health Care, 21 HeALTH AFF. 185 (Mar./Apr. 2002), available at http://content.healthaffairs.org/cgi/reprint/21/2/185.pdf. 
efficient integration can take place, and protecting patients from low quality care. ${ }^{10}$ On closer inspection (by the antitrust agencies, courts, and Congress) these explanations have been found wanting. Even where legitimate concerns are raised, the mechanism sought — collective bargaining — was designed to shield physicians from market discipline with no guarantee that the promised benefits to the consumer would be realized. Where plausible economic arguments supported factoring into the analysis other market conditions, such as quality of care, imperfect information, or the charitable mission of nonprofit hospitals, antitrust law turned a deaf ear. ${ }^{11}$ Prompted by both pragmatic considerations and suggestive legal precedent, enforcers used standard microeconomic analysis, framing health care as functioning "like any other industry." It should be noted that antitrust enforcement has been directed, with varying degrees of intensity (and only mixed success), at other sectors of the health care market. For example, enforcers have focused only sporadic efforts on dealing with problems in "upstream" markets, such as device and ancillary equipment suppliers. ${ }^{12}$ In other areas aggressive enforcement has met with resistance from the courts. The FTC has devoted extensive resources in the past five years to dealing with abuses of intellectual property in the pharmaceutical industry, challenging agreements that kept generic drugs from entering the markets of brand name rivals, and mergers and abuses of the patent system designed to improperly obtain or maintain monopoly power. ${ }^{13}$ Despite the fact that reverse payment settlements and certain abuses of the patent system have enabled manufacturers of branded pharmaceuticals to reap extraordinary monopoly rents, some courts have excused them, based on a presumption of validity in demonstrating the

10. Robert Pitofsky, Chairman, Federal Trade Comm'n, Thoughts on "Leveling the Playing Field in Health Care," Remarks at the National Health Lawyers Association Twentieth Annual Program on Antitrust in the Health Care Field (Feb. 13, 1997), available at http://www.ftc.gov/speeches/pitofsky/ nhla.shtm.

11. See Peter J. Hammer \& William M. Sage, Antitrust Law, Healthcare Quality and the Courts, 102 Colum. L. ReV. 545 (2002); Thomas L. Greaney, Antitrust and Hospital Mergers: Does the Nonprofit Form Affect Competitive Substance?, 31 J. HeALTH POL. POL'Y \& L. 511 (2006).

12. The FTC Competition Enforcement Database lists only five actions, all involving mergers, involving medical devices since 2004. See http://www.ftc.gov/bc/caselist/industry/cases/healthcare/ HealthCareMedicalEquipment.pdf.

13. See, e.g., Schering-Plough Corp. v. Fed. Trade Comm'n, 402 F.3d 1056 (11th Cir. 2005). The "reverse payments" cases have generated an enormous literature debating a host of economic and doctrinal issues. See, e.g., Herbert Hovenkamp, Mark Janis \& Mark A. Lemley, Anticompetitive Settlement of Intellectual Property Disputes, 87 MinN. L. REV. 1719, 1720-21 (2003); Carl Shapiro, Antitrust Limits to Patent Settlements, 34 RAND J. ECON. 391 (2003); James Langenfeld \& Wenqing Li, Intellectual Property and Agreements to Settle Patent Disputes: The Case of Settlement Agreements with Payments from Branded to Generic Drug Manufacturers, 70 ANTITRUST L.J. 777 (2003). 
agreements' reasonableness. ${ }^{14}$ Finally, in several important areas, such as anticompetitive exclusion by group purchasing organizations and pharmaceutical benefit managers, in which conflicts of interest may cause serious impediments to market entry and innovation, governmental antitrust enforcers have been relatively quiescent. ${ }^{15}$

Provider market structure has also been a key target of antitrust enforcement efforts. Federal and state enforcers have litigated more than thirty hospital merger cases and dozens more have been settled or abandoned. On a much smaller scale, anticompetitive linkages between hospitals and physicians in physician-hospital organizations have occasionally been challenged ${ }^{16}$ and a few anticompetitive hospital networks ${ }^{17}$ have come under scrutiny. These cases were consistent with the view that the success of managed care competition hinged on the preservation of competitive providers markets. The theme of encouraging market structures in which managed care entities could successfully "play providers off against each other" through competitive bidding or negotiations was the hallmark of the federal antitrust strategy. At the same time, antitrust enforcers were relatively passive with regard to vertical combinations and managed care mergers. While a handful of cases were brought challenging monopsonistic ("buy side") abuses or monopolypreserving ("sell side") conduct by large health insurers and a few mergers involving large national firms resulted in spin offs of a handful of contracts, little attention was directed at managed care companies. ${ }^{18}$ The agencies

14. How Pay-for-Delay Settlements Make Consumers and the Federal Government Pay More for Much Needed Drugs, Prepared Statement Before the H. Subcomm. on Commerce, Trade, and Consumer Protection Comm. on Energy and Commerce, 11 th Cong. (2009) (Statement of Thomas Rosch, Comm'r, Fed. Trade Comm'n), available at http://www.ftc.gov/os/2009/03/P859910payfordelay.pdf.

15. See Letter from Sen. Mark Montigny to FTC Chairman Deborah Platt Majoras, May 11, 2005 (on file with the FTC) (letter from bipartisan group of state legislators urging investigation of PBM industry, noting that "numerous states are devoting considerable enforcement resources to combating fraudulent and anticompetitive conduct by PBMs").

16. See, e.g., United States v. HealthCare Partners, Inc., 1996-1 Trade Cas. (CCH) \ 71337, 1996 WL 193753 (D. Conn. 1996) (consent decree) (settling claims that PHO's over-inclusive panel of physicians would foreclose competition).

17. See Letter from David R. Pender, Acting Assistant Dir., Bureau of Competition, FTC, to Clifton E. Johnson (Mar. 28, 2006) (FTC Staff Advisory Opinion) (on file with the FTC) (unfavorable advisory opinion involving "super PHO" consisting of eight hospitals).

18. See United States v. UnitedHealth Group Inc., Case No. 05CV02436 (D.D.C. 2006) (merger of UnitedHealth Group Inc. and PacifiCare Health Systems, Inc.); see also United States v. UnitedHealth Group Inc., Case No. 08-cv-00322 (D.D.C. 2008) (merger of UnitedHealth Group Inc. and Sierra Health Services, Inc.). Recently, in reviewing the proposed merger of Highmark Inc. and Independence Blue Cross, state regulators found significant competitive issues (despite the fact that the U.S. Department of Justice had not objected to the merger) and imposed preconditions that led to the parties abandoning the merger. See Two Pennsylvania Blue Cross Plans Abandon Two-Year Effort to Consolidate, Health L. ReP. (BNA) 
questioned the American Medical Association's (AMA) repeated claims that oligopolistic managed care markets impeded competition, concluding instead that local insurance markets for the most part were competitively structured and lacked significant barriers to entry. ${ }^{19}$

Although initially successful in breaking down institutional barriers to competition and challenging hospital mergers, antitrust enforcement efforts have encountered a number of problems over the last decade. Most significantly, federal and state antitrust agencies experienced a series of seven consecutive defeats in federal court challenges to hospital mergers. ${ }^{20}$ As discussed below, the decisions in those cases can be faulted on a number of grounds: failure to incorporate a sophisticated understanding of the market imperfection of health care markets, poor case selection by the government, and to some extent, a judicial backlash against managed care. However, the government's spotty record in litigation may be offset somewhat by its extensive efforts to secure voluntary compliance with the law and adoption of organizational structures that do not directly impede competition.

The second prong of antitrust enforcement sought to focus the agencies' enforcement apparatus on creating an environment conducive to managed care competition. This "apparatus" is a variety of formal and informal tools used by the agencies outside the narrow bounds of prosecuting antitrust abuses in judicial and administrative hearings. It includes settlements and consent decrees, speeches, advisory opinions, advice to legislators, and policy statements. ${ }^{21}$ Because they encourage adoption of structures and arrangements

(Jan. 19, 2009).

19. See Federal Trade Commission \& U.S. Dept. of Justice, Improving Health Care: A Dose of COMPETITION at ch. 6 (2004); see also David A. Hyman \& William E. Kovacic, Monopoly, Monopsony, and Market Definition: An Antitrust Perspective on Market Concentration Among Health Insurers, 23(6) HEALTH AFF. 25, 27 (2004) (summarizing report as concluding that employers find most insurance markets enjoy "healthy competition" and that "most employers can self-insure and thereby avoid most of the problems that might otherwise result from health insurance market concentration").

20. See Thomas L. Greaney, Chicago's Procrustean Bed: Applying Antitrust in Health Care, 71 ANTITRUST L.J. 857 (2004). Seeking to right their ship, the FTC challenged an already-consummated merger involving two nonprofit hospitals in Evanston, Ill. In re Evanston Northwestern Hospital, FTC Docket No. 9315 (Aug. 6, 2007), available at www.ftc.gov/os/adjpro/d9315/070806opinion.pdf. After finding the acquisition violated the Clayton Act, the Commission declined to require structural relief, instead ordering that the merged hospitals form separate and independent negotiating teams to contract with managed care organizations.

21. See Greaney, Regulating for Efficiency in Health Care, supra note 4; see also Deborah Platt Majoras, Chairman, FTC, Remarks at the World Congress Leadership Summit: The Federal Trade Commission: Fostering a Competitive Health Care Environment That Benefits Patients (Feb. 28, 2005), available at $\mathrm{http}: / / \mathrm{www} . \mathrm{ftc}$. gov/speeches/majoras/050301 healthcare.pdf:

$[\mathrm{L}] \mathrm{aw}$ enforcement is not the only procedure we use to cure anticompetitive ailments. The FTC 
that avoid antitrust risk, these tools have a distinctly prescriptive flavor. While these undertakings controversially enmeshed the agencies in "regulation" (as opposed to seeking remedies by adjudication litigation), they also afforded an opportunity to direct providers and payors toward economically sound arrangements given the peculiarities of health care markets.

In pursing these undertakings, countering fragmentation was a prominent objective of the government's implied regulatory agenda. In dispensing advice and negotiating settlements the agencies stressed the desirability of integrating independent providers. The FTC and DOJ afforded safe harbor treatment for financial risk sharing in their policy statements, and repeatedly signaled in speeches and advisory opinions that they strongly favored integration via risk sharing or formation of fully integrated firms and partnerships. ${ }^{22}$ In eventually countenancing "clinical integration" as an alternative form of cooperation that could avoid summary condemnation, the agencies took pains to stipulate detailed conditions evidencing the sufficiency of integration and the necessity for price agreements. ${ }^{23}$

Though criticized as overly prescriptive, ${ }^{24}$ the agencies' insistence on specific integrative activities was entirely appropriate in view of the market imperfections that plague the industry. Risk-sharing mechanisms, especially capitation and fee withholds, counteract the incentives of compensation systems to over-provide medical care. Without a strong commitment to the cooperative enterprise (such as a physician's ownership in a thinly capitalized network), incentives are lacking to counter the fee-for-service payment hydraulic promoting costly and excessive care. As Peter Hammer summarized the prevailing incentive structure, "[Unintegrated] networks can be expected to maximize profits both by using whatever market power they possess to

actively engages in advocacy before states and other federal Agencies, urging the adoption of pro competitive strategies for improving health care quality and bringing costs down. . . . $[\mathrm{A}]$ dvocacy can be very effective. Competition advocacy ... can prevent legislation that might unintentionally injure competition — and raise patients' costs—-from getting on the books in the first place.

22. See, e.g., Letter from Jeffrey W. Brennan, Assistant Dir., Bureau of Competition, FTC, to Martin J. Thompson (Sept. 23, 2003) (on file with the FTC) (Staff Advisory Opinion to Bay Area Preferred Physicians) [BAPP Advisory Opinion]; Letter from Jeffrey W. Brennan, Assistant Dir., Bureau of Competition, FTC, to Gregory G. Binford (Feb. 6, 2003) (on file with the FTC) (Staff Advisory Opinion to PriMed Physicians).

23. FTC Staff Advisory Opinion to TriState Health Partners, Inc. (Apr. 7, 2009), available at http://www.ftc.gov/os/closings/staff/090413tristateaoletter.pdf; Letter from Jeffrey W. Brennan, Assistant Dir., Bureau of Competition, FTC, to John J. Miles (Feb. 19, 2002) (Staff Advisory Opinion to MedSouth, Inc.) [MedSouth Advisory Opinion]. See also Rosch, Clinical Integration, supra note 5.

24. Havighurst, supra note 7. 
charge higher prices and by practicing medicine using traditional standards which are intrinsically biased in favor of over-providing care." ${ }^{25}$ Thus antitrust policy sensibly targeted fragmented delivery arrangements and encouraged integration. However, for reasons discussed in the next section, neither the nudge of law enforcement nor the pressure of managed care bargaining proved sufficient to unseat entrenched provider arrangements.

\section{Antitrust as a (Mostly Unsuccessful) Antidote to Fragmentation}

Superficially viewed, the antitrust agenda might seem to increase fragmentation as it prevents aggregation of providers into large entities or cooperation through alliances with competitors. However, economic theory predicts the opposite result. A central (some say exclusive) objective of antitrust is fostering efficiency. Hence antitrust doctrine promotes efficiencyenhancing integration, including mergers, joint ventures, and other forms of cooperation, between rivals and between entities in vertical relationships. Indeed, theory and experience teach that competitive markets should act to stimulate inter-firm cooperation through organizational structures and encourage agreements that improve performance and lower costs. Properly applied, antitrust law should promote decentralized decision-making by market participants while encouraging efficient combinations that serve consumer welfare.

Yet in health care, this rosy scenario has not come to pass, as antitrust enforcement had at best only modest success in encouraging efficient consolidation of providers. The disparity between the predictions of conventional microeconomics and marketplace experience exposes the power of what Kenneth J. Arrow termed "nonmarket forces" in health care. ${ }^{26}$ Multiple factors contributed but it seems clear that the deeply entrenched norms, institutional structures, and legal regimes that have long supported fragmentation enabled providers to resist change. As a result, innovations in care delivery, organization, and financing that competition theorists thought inevitable did not spread. Providers remained content to practice in silos, though some sectors such as hospitals and certain physician specialties formed

25. Peter J. Hammer, Medical Antitrust Reform: Arrow, Coase, and the Changing Structure of the Firm, in The Privatization of Health Care Reform 113, 115-16 (M. Gregg Bloche ed., 2003). See also Rosch, Clinical Integration, supra note 5 (noting that "financial incentives are the safest way to proceed" given uncertainties about the incentives and implementation of clinical integration).

26. Kenneth J. Arrow, Uncertainty and the Welfare Economics of Medical Care, 53 AM. ECON. REV. 941 (1963). 
local monopolies or oligopolies to further insulate themselves from rivalry. Legal and regulatory factors also play a part in determining the path of markets. As discussed below, questionable holdings in key cases and conflicting signals from other legal regimes legitimated these arrangements and ultimately the antitrust agenda did not generate the integrated systems or virtual networks needed for competition to have any serious bite.

Fragmentation at the provider level frustrated competition policy in a number of ways. For the large percentage of physicians practicing in small groups or single specialty practices, adapting to managed care's incentives for risk sharing and economizing practices was extraordinarily difficult. ${ }^{27}$ Many physicians proved inept in assessing risk. In both clinical and economic decision-making such as dealing with capitation, physicians are subject to problems of over optimism, endowment bias, and other departures from rational choice models as identified by behavioral decision theorists. ${ }^{28}$ At the same time, physicians jealously guarded their independence and were resistant to undertaking employment relationships or joining staff model HMOs or large practice groups. In the dozens of cases described earlier, groups of physicians formed thinly disguised cartels to gain market power to bargain with managed care companies. Elsewhere, physicians flocked to loosely structured Preferred Provider Organizations (PPOs) that did little to promote price competition or instill incentives to change practice styles. ${ }^{29}$ Further, the absence of vertical integration also frustrated managed care's performance. In hospital markets, in which most patients delegate hospital choice to their physicians (who do not internalize the costs of technology or excess capacity), hospitals benefited more by competing for physician affiliation (though various forms of nonprice competition) than by economizing for the benefit of contracting. The net result was proliferation of "networks" that did little to change practice patterns and entrenchment of market structures that served as bulwarks against effective bargaining by managed care organizations.

Fragmentation arising out of health care financing exacerbated these problems and served to undermine managed care's incentives to promote development of efficient delivery organizations. With physicians typically contracting with multiple payors, incentives to change practice styles or adopt other methods for controlling cost or improving quality to conform to

27. See infra note 28 and accompanying text

28. See Thomas L. Greaney, Economic Regulation of Physicians: A Behavioral Economics Perspective, 53 ST. LOUIS U. L.J. 1189 (2009).

29. Bryan E. Dowd, Coordinated Agency Versus Autonomous Consumers in Health Care Markets, 24 HeAlth AFF. 1501 (Nov./Dec. 2006). 
protocols of any single payor are attenuated. In addition, fee-for-service payment neglects many of the services key to developing integrated approaches to delivery. For example, it fails to pay for care coordination and information exchanges, and it undervalues other valuable services such as cognitive services and communications outside care encounters. Given dominant payment methodologies rewarding physicians who do not integrate their practice arrangements, and organized medicine's longstanding resistance to organizational hierarchies, it is not altogether surprising that managed care's competitive incentives failed to deliver change.

The antitrust agenda also encountered serious litigation setbacks. Courts rejected a succession of FTC and DOJ challenges to hospital mergers and enforcers subsequently backed off monitoring the hospital sector. As discussed in the following section, local hospital markets around the country became highly concentrated. Paradoxically, this consolidation also served to reinforce health sector fragmentation. It did so by strengthening hospitals' market power and hence their ability to resist managed care demands for economizing practices, such as forming integrated delivery system with physicians. Underlying these judicial decisions is a persistent failure to adapt legal analyses to the peculiar economics of competition in the health care sector. The principal shortcoming was the courts' tendency to oversimplify antitrust analysis by adopting simplistic, Chicago-school assumptions about markets while failing to incorporate the effects of market imperfections in their analyses of health markets. ${ }^{30}$ As a result, most of these hospital merger decisions found extraordinarily large geographic markets for basic acute care hospital services by failing to appreciate the heterogeneity of demand for care and the fact that consumers exhibit different preferences for travel. Other cases refused to recognize supply side heterogeneity, failing to appreciate that mergers of "must have" hospitals may create risks of anticompetitive effects. ${ }^{31}$ Health economists and commentators have roundly criticized these decisions as inconsistent with the economic realities of local competition and for

30. Thomas L. Greaney, Chicago's Procrustean Bed: Applying Antitrust Law in Health Care, 71 ANTITRUST L.J. 857 (2004) (emerging critique of conventional antitrust wisdom applies the teaching of behavioral economics). See Maurice E. Stucke, Behavioral Economics at the Gate: Antitrust in the TwentyFirst Century, 38 Loy. U. CHI. L. REV. 513, 527-28 (2007). See generally Russell B. Korobkin \& Thomas S. Ulen, Law \& Behavioral Science: Removing the Rationality Assumption from Law \& Economics, 88 CAL. L. ReV. 1051-1102 (2000); Christine Jolls et al., A Behavioral Approach to Law \& Economics, 50 StAN. L. REV. 1471 (1998). For applications in several areas of health care law, see Greaney, supra note 28.

31. United States v. Long Island Jewish Med. Ctr., 983 F. Supp. 121 (E.D.N.Y. 1997). 
misapprehending the interplay of managed care organizations (MCOs), employers, and insured persons in selecting hospitals. ${ }^{32}$

Legal analyses are not immune to the biases and preconceptions prevalent in the society at large. In refusing to enjoin hospital mergers and rejecting other antitrust challenges to provider market power, courts may have internalized skepticism about health care insurers-popularly characterized as a "managed care backlash." Betraying a strong undercurrent of suspicion about the role of managed care, for example, one federal Circuit decision quoted Judge Richard Posner's hyperbolic dictum that 'the HMO's incentive is to keep you healthy if it can but if you get very sick, and are unlikely to recover to a healthy state involving few medical expenses, to let you die as quickly and cheaply as possible." ${ }^{\prime 33}$ Other courts have revealed these assumptions more explicitly in holdings downplaying testimony from managed care buyers ${ }^{34}$ or suggesting that competition resulting from rivalry among such entities was not in consumers' interest. ${ }^{35}$ Furthermore, one federal court and some state attorneys general accepted consent decrees allowing mergers to proceed subject to regulatory controls on profits, price, and charitable care as a substitute for preserving market structures conducive to price competition. ${ }^{36}$ Thus it is possible to discern in the case law an implicit suspicion of the competition paradigm on which antitrust enforcement rested, namely vigorous bargaining by managed care organizations exerting pressure on providers to reorganize themselves to adopt more cost-efficient arrangements.

Another factor contributing to the failure of competitive forces to encourage defragmentation of markets is the regulatory environment governing providers. Several significant legal regimes directly impede efficiency-enhancing cooperation among rivals. The federal anti-kickback and Stark laws bar many forms of vertical and horizontal cooperation that can

32. See, e.g., Kenneth L. Danger \& H.E. Frech, Critical Thinking About "Critical Loss" in Antitrust, 46 ANTITRust Bull. 339 (2001); James Langenfeld \& Wenqing Li, Critical Loss Analysis in Evaluating Mergers, 46 AnTiTRust Bull. 299 (2001); Gregory Vistnes, Hospitals, Mergers, and TwoStage Hospital Competition, 67 ANTITRUST L.J. 671 (2000).

33. FTC v. Tenet Health Care Corp., 186 F.3d 1045, 1054 (8th Cir. 1999) (quoting Blue Cross \& Blue Shield United v. Marshfield Clinic, 65 F.3d 1406, 1410 (7th Cir. 1995)).

34. Id.

35. FTC v. Butterworth Health Corp., 946 F. Supp. 1285, 1299 (W.D. Mich. 1996) (questioning the benefits of managed care contracting and concluding that "selective price advantages are hardly the sort of benefit the antitrust laws are designed to protect").

36. FTC v. Butterworth Health Corp., 946 F. Supp. 1285, 1291 (W.D. Mich. 1996). 
improve efficiency. ${ }^{37}$ Consequently, the fragmented community of physicians and hospitals is prevented from responding to competitive market incentives to integrate via joint ventures and contractual arrangements. More than any other regulatory obstacle, the inability of hospitals to share efficiency and cost-effective improvements with physicians who order services impedes effective deployment of health resources. ${ }^{38}$

Another cluster of laws operate to impair the development of efficient "firms," or contractual arrangements that bridge traditional doctor-hospital boundaries. State certificate of need laws, for example, impair competition in acute care and some ambulatory services. ${ }^{39}$ These laws, which create barriers to entry by rivals, especially physicians seeking to open specialty hospitals or ambulatory surgery centers, contribute indirectly to health sector fragmentation. They do so by institutionalizing existing physician-hospital relationships, essentially ossifying traditional, autonomous roles. By erecting barriers for physicians wanting to operate ambulatory surgical facilities or acute care specialty hospitals, these laws significantly reduce opportunities for integrated service delivery. Adding to the problem is another body of law recognized in approximately a dozen states, the corporate practice of medicine doctrine, which inhibits medical professionals from working in employment relationships and prohibits corporate entities from assuming responsibility for the provision of services. ${ }^{40}$ This doctrine prohibits (or imposes significant transaction costs on) arrangements between physicians and corporate entities that provide health care services. As such it operates to reduce opportunities establishing "firms" that can more efficiently organize care delivery. Finally, a network of other laws and regulations, including the Joint Commission on Accreditation of Healthcare Organizations (JCAHO) certification standards, ${ }^{41}$ and those governing physician responsibilities and rights in hospital

37. See James F. Blumstein, The Fraud and Abuse Statute in an Evolving Health Care Marketplace: Life in the Health Care Speakeasy, 22 AM. J.L. \& MED. 205 (1996); David A. Hyman, Health Care Fraud and Abuse, Social Norms, and "The Trust Reposed in the Workmen, " J. LEgAL STUDIES 531 (2001).

38. See Gail Wilensky et al., Gain Sharing: A Good Concept Getting a Bad Name?, 26 HeALTH AFF. 58 (2007).

39. See Federal Trade Commission \& U.S. Dept. of Justice, supra note 19, at 6 (summarizing evidence regarding the impact of $\mathrm{CON}$ laws on competition and cost control and urging states to reconsider whether CON laws are serving the public interest).

40. See, e.g., Berlin v. Sarah Bush Lincoln Health Center, 688 N.E.2d 106 (Ill. 1997); see generally Mark A. Hall, Institutional Control of Physician Behavior, 137 U. PA. L. REV. 431 (1988).

41. See James F. Blumstein, Of Doctors and Hospitals: Setting the Analytical and Regulatory Framework for Managing the Relationship, 4 IND. HEALTH L. REV. 211, 222-25 (2007). 
management, ${ }^{42}$ solidify professional autonomy within hospitals and reinforce barriers to hospitals asserting greater control to integrate their operations in a cost-effective manner.

The preceding catalogue of obstacles to integration should not be understood to suggest that competition theorists had everything right. Indeed, the brief that competition advocates presented for the capacity of managed care to address market failure overlooked several important obstacles. ${ }^{43}$ For example, although it provided an effective mechanism for alleviating agency and information problems among providers, patients, and payors, managed care by itself could not address the serious information deficits respecting quality and outcomes. As public goods, such information is under produced in the market and requires government action though subsidy or direct provision. ${ }^{44}$ Although government policies in administering and financing public programs such as Medicare might have served this function, they did not. In addition, market theorists generally overlooked the fact that market failure can be exacerbated or perpetuated by "government failure"- public policies that entrench market imperfections. To cite a few examples, federal tax policy supported moral hazard in insurance; fee-for-service payment under Medicare reinforced physician agency problems and countenanced costineffective practice styles; and licensure and accreditation imposed entry and mobility barriers on providers.

42. See John D. Blum, Beyond the Bylaws: Hospital-Physician Relationships, Economics, and Conflicting Agendas, 53 BufF. L. Rev. 459 (2005); see also John P. Marren et al., Hospital Boards at Risk and the Need to Restructure the Relationship with the Medical Staff: Bylaws, Peer Review and Related Solutions, 12 AnNALS HeALTH L. 179, 207-12 (2003).

43. See Thomas L. Greaney, Competitive Reform in Health Care: The Vulnerable Revolution, 5 YALE. J. ON REG. 179 (1988) (predicting that competition in health care would not succeed if regulatory and infrastructure did not support it).

44. Paul Ginsburg summarized the need for public and private initiatives to improve technology assessment as follows:

Over the long haul, advancements in medical technology are far and away the biggest factor in rising costs. And our current financing system facilitates the rapid diffusion of expensive new technologies by paying most of their cost-even in the absence of careful consideration of their clinical effectiveness relative to existing treatments. Fundamental change in this dynamic would require support for improved and more frequent evaluation of new technologies prior to decisions about coverage, as well as carefully differentiated incentives built into the financing system that encourage both providers and patients to evaluate the clinical effectiveness of a given course of treatment against its cost.

Tax Exemption: Pricing Practices of Hospitals Before the Subcomm. on Oversight, House Ways and Means Comm., 108th Cong. (2004) (Statement of Paul Ginsburg, Center for Studying Health System Change). 


\section{AFTERMATH: CONCENTRATION AND FRAGMENTATION IN A DISINTERMEDIATED MARKET}

Following the government's defeats in the hospital merger cases, an extraordinary consolidation occurred in hospital and insurance markets. Emboldened by the results in those cases and the government's ensuing reluctance to challenge mergers in court, concentration grew significantly in almost all sectors of health care delivery and payment. Hundreds of hospital mergers occurred in the 1990s, and by 2003 ninety-three percent of the nation's population lived in concentrated hospital markets. ${ }^{45}$ In local acute care hospital markets the effects of concentration were striking. Research demonstrates that hospital consolidation in the 1990s raised overall inpatient prices by at least five percent and by forty percent or more when merging hospitals were closely located. ${ }^{46}$ Anecdotal evidence confirms that payers in many local markets faced increased resistance to bargaining by hospitals and that this led to higher prices. ${ }^{47}$ Besides price increases owing to enhanced bargaining power, increases in hospital costs appear to be driven by strategic decisions that take advantage of market imperfections. By some accounts, the "medical arms race" has resurfaced, as hospitals have undertaken significant expansions in high margin services and accelerated technology acquisitions, in part owing to their capacity to induce demand following the demise of managed care. ${ }^{48}$

Consolidation in local hospital markets does not appear to have produced significant scale economies or other efficiencies that would benefit consumers. The literature on multihospital system performance shows little evidence of improvement in cost per admission, profitability or service provision to the community in the form of charity. ${ }^{49}$ Likewise, hospital

45. The Synthesis Project, Robert Woods Johnson Foundation, How Has Hospital CONSOLIDATION AFFECTED THE PRICE AND Quality OF Hospital CARE 1 (2006).

46. See id. (citing simulation studies show price increases of 53 percent; event studies indicating 40 percent increases; and Structure-Conduct Performance studies showing 4-6 percent increases); see also Robert Town et al., The Welfare Consequences of Hospital Mergers (National Bureau of Econ. Research, Working Paper No. 12244, 2006) (demonstrating that hospital mergers raised HMO premiums 3.2 percent and caused 0.3 percent decline in private insurance in 2001).

47. See Center for Study of Health Systems Change, CTS Site Visits (periodic survey of competitive conditions in 12 markets), http://www.hschange.com/index.cgi?data $=06$.

48. See Robert A. Berenson et al., Hospital-Physician Relations: Cooperation, Competition, or Separation?, Health AfF. Web Exclusive (Dec. 5, 2006), http://content.healthaffairs.org/cgi/reprint/ $25 / 5 /$ w337.

49. See Lawton R. Burns \& Mark V. Pauly, Integrated Delivery Networks: A Detour on the Road to Integrated Health Care?, 24 HEALTH AFF. 128 (2002) (summarizing studies of horizontal hospital 
networks and alliances did not exhibit significant economies or other efficiencies. ${ }^{50}$ The evidence on the effect of hospital mergers on quality is mixed. A recent summary of the literature states that "the majority of studies find that hospital mergers lower quality," and that result is supported by the strongest studies. ${ }^{51}$

In sum, the extensive hospital consolidation that occurred in the 1990s cannot be interpreted as a welfare-improving correction to market fragmentation. Instead, the merger wave is best understood as a successful effort to gain leverage in the marketplace, which hospitals used to deflect the price and volume discipline threatened by managed care contracting. At the same time, efforts at vertical integration (between hospitals and physicians and between providers and insurers) came to a halt.

Competition in physician markets during the managed care era followed a completely different path, but also failed to rationalize market structures or produce effective rivalry. As discussed below, physicians did not engage in widespread horizontal merger activity in the 1990s, and although the percentage of doctors in small practices declined, this market remained fragmented as multi-specialty practice did not increase significantly. ${ }^{52}$ However, throughout that period and beyond, physicians engaged in extensive cartelization. Between 1976 and 1996, the FTC and the DOJ initiated and settled by consent decrees approximately sixty-five enforcement actions against hospital and physician-contracting networks for jointly negotiating on behalf of their members with payors in a manner that constituted unlawful horizontal price-fixing agreements. ${ }^{53}$ Remarkably, this vigorous record of prosecution did not deter the challenged conduct. Since the beginning of this decade, the FTC has brought thirty-four such cases and the Antitrust Division of the DOJ challenged at least five similar arrangements as illegal horizontal restraints. The government's willingness to accept "wrist slap" consent decrees, and the adoption of an administrative rather than a prosecutorial approach to the problem, helps explain the widespread lack of compliance

mergers).

50. Id.; see also Gloria J. Bazzoli et al., The Financial Performance of Hospitals Belonging to Health Networks and Systems, 37 INQUIRY 234 (2000).

51. The Synthesis Project, supra note 45, at 3; see also Vivian Ho \& Barton H. Hamilton, Hospital Mergers and Acquisitions: Does the Market Consolidation Harm Patients?, 19 J. Health Econ. 767 (2000).

52. See infra note 53 and accompanying text.

53. See Thomas L. Greaney, Thirty Years of Solicitude: Antitrust and Physician Cartels, 7 Hous. J. HEALTH L. \& POL. 189, 190 (2007). 
with antitrust norms.$^{54}$ Notably absent in the government's prosecutions were criminal and structural remedies or stringent civil remedies.

Finally, the health insurance market has undergone significant consolidation as there have been over four hundred health insurer mergers in the past decade and virtually every major metropolitan market is highly concentrated. With premiums increasing over eighty-seven percent over the past six years, insurance market concentration has engendered considerable controversy. ${ }^{55}$ However, antitrust challenges to insurer mergers or conduct have been few and far between. In the past seven years, the DOJ has only required the restructuring of two proposed health insurance mergers, both with very modest divestitures. In the view of the federal agencies, insurer market power has not been significant, owing to perceived ease of entry and self insurance alternatives available to large employers. Though not expressly acknowledged, the agencies' lenient posture may reflect the view that managed care serves as an important counterweight to the power of providers. In essence, the government may have adopted what it viewed as a second-best strategy under which it is hoped that bilateral monopoly will achieve some measure of benefit to consumers. It should be noted that this view is disputed by those who assert that managed care competition has resulted in higher prices to consumers and monopsony input pricing for physicians. ${ }^{56}$

Current trends in physician organization suggest that the structure of medical services delivery is moving in the wrong direction. There is considerable evidence that large multispecialty groups offer clinically superior and seamless delivery of care and perform better in terms of collecting and distributing information, thereby improving quality. ${ }^{57} \mathrm{~A}$ well functioning financing system should encourage physicians to join such organizations in order to attract more patients by providing higher quality, cost effective care. Indeed, during the managed care era, there was perceptible movement away from solo and small group physician practice, and in some markets,

54. See id. at 196. See also Rosch, Clinical Integration, supra note 5, at 2.

55. See Consolidation in the Pennsylvania Insurance Market: The Right Prescription? Before the Subcomm. on Antitrust, Competition Policy, and Consumer Rights, Comm. on the Judiciary (2008) (statement of Henry S. Allen, American Medical Association), http://judiciary.senate.gov/pdf/08-0731Allen_Testimony.pdf.

56. See Consolidation in the Pennsylvania Insurance Market: The Right Prescription?, Before the S. Comm. on the Judiciary, 110th Cong. (2008) (statement of David Balto), http://judiciary.senate.gov/pdf/ 08-07-31.

57. See Toward of 21st Century Health System: The Contribution AND Promise of PrePaid Group Practice (Alain Enthoven \& Laura A. Tolen eds., 2004); STEVEN SHORTELL ET AL., REMAKING HeAlth CARE IN AmERICA: BuILding ORganized Delivery Systems (1996). 
considerable growth among multispecialty groups. However, as managed care receded, specialists began to move to mid-size, single specialty groups, which provide less opportunity for quality improvement. As the Center for Studying Health System Change has concluded, financial incentives under the evolving insurance arrangements rewarded migration to inefficient organizational forms. Large single-specialty groups are able to gain market power to negotiate higher reimbursement without suffering penalties for higher costs or lower quality. ${ }^{58}$ Furthermore, these groups can assemble capital in order to capitalize on flaws in the payment system, typically by moving into high reimbursement, capital intensive services and opportunistically engaging in self-referral as permitted under exceptions to anti-self referral laws. ${ }^{59}$

Changes in financing have also altered the dynamics of competition in hospital markets. As noted earlier, concentration in many acute care hospital markets has given hospitals leverage to extract monopoly rents. In addition, the overall shift to passive contracting by insurers has undermined efficient resource allocation in hospital markets. As Berenson, Bodenheimer, and Pham describe these changes:

\begin{abstract}
With the decline of risk contracting and a return to fee-for-service payment, hospitals were relieved of the need to manage costs for defined populations. They returned to the traditional business model of filling beds with well-insured patients. Faced with growing competition for patients, both from other hospitals and from ambulatorybased care, hospitals quickly adopted strategies dedicated to increasing the flow of patients into the hospital. In short, hospitals resumed what in the 1980s [was] described as a "medical arms race," a form of competition tending to increase, rather than reduce, costs. $^{60}$
\end{abstract}

Further, physicians have seized upon emerging conditions to compete directly with hospitals, acquiring ownership interests in specialty hospitals, ambulatory surgery centers, diagnostic imaging facilities, and other ancillary service facilities. Anecdotal evidence, including interviews with employers and third party payers, suggests that providers are able to exploit their agency relationship to induce demand and shift the locus of care to the facilities in which they have ownership interests. ${ }^{61}$

58. Hoangmai H. Pham \& Paul B. Ginsburg, Unhealthy Trends: The Future of Physician Services, 26 HeAlth AfF. 1586, 1593 (2007).

59. Id. at $1592-93$.

60. Robert A. Berenson et al., Specialty-Service Lines: Salvos in the New Medical Arms Race, HeAlth AfF. Web EXCLUSIVE w337, w338 (2006), http://content.healthaffairs.org/cgi/reprint/25/5/w337.

61. Berenson et al., supra note 48 , at w31. 
These developments have created new opportunities for both competition and collusion between hospitals and doctors. ${ }^{62}$ In some cases, hospitals have established joint ventures with their physicians primarily as a defensive move, while in others they have acted to counter rivals by using techniques ranging from vigorous competition to anticompetitive exclusionary tactics. From the perspective of competition policy the import of emerging physician-hospital rivalry depends on the specifics of the markets involved. ${ }^{63}$ In some cases, physician-owned entities may offer a valuable source of new competition in oligopolistic hospital markets; in others, the physicians may be externalizing costs on rival community hospitals. In the absence of a mediating influence of third party payers, responsibility for sorting out the "pro" and "anti" competitive cases will fall on legislators, regulators, or antitrust enforcers.

\section{Consumer Driven Health Care: A Flawed Vehicle for Change}

The preceding analysis suggests that managed care competition did not alleviate, and probably fell victim to, provider market fragmentation. Over the last ten years health insurers have retreated from active management of care and a new market-oriented approach, "consumer directed health care" (CDHC), has emerged. While that phrase covers a lot of ground, as used here it reflects the broad shift of responsibility for choice and cost to consumers. ${ }^{64}$ Relying increasingly on large co-payments, deductibles, and various benefit designs, insurance plans offer benefits packages that create incentives for consumers to take more responsibility to choose the nature and intensity of health services and the providers who provide that care. Beyond the trend toward higher deductibles and co-payments, consumer directed plans sometimes are linked with health reimbursement accounts, which are dedicated funds supplied by employer and/or employee contributions that can

62. See, e.g., Rome Ambulatory Surgery Ctr. v. Rome Mem'l Hosp., 349 F. Supp. 2 d 389 (N.D.N.Y. 2004); Gordon v. Lewiston Hosp., 272 F. Supp. 2d 393 (M.D. Pa. 2003). See also Mahan v. Avera St. Luke's, 621 N.W.2d 150 (S.D. 2001).

63. An analysis of the underlying economic relationships suggests that in the hospital setting, staff physicians and hospitals provide complementary products and each side benefits from free rider benefits of its association with the other. See David A. Argue, An Economic Model of Competition Between General Hospitals and Physician-Owned Specialty Practices, Antitrust HealthCARe Chron. (2006). Application of antitrust principles to disputes involving hospitals' reactions to specialty hospital competition needs to closely evaluate these relationships in order to determine whether plausible efficiencies justify challenged conduct.

64. See Timothy S. Jost, Health Care at Risk: A Critique of the Consumer Driven Movement (2007); John V. Jacobi, After Managed Care: Gray Boxes, Tiers and Consumerism, 47 ST. LOUIS U. L.J. 397 (2003). 
be used to pay for certain expenses and medical services. ${ }^{65}$ One rapidly growing variant, the health savings account (HSA), carries with it important tax benefits such as allowing taxpayers to exclude funds placed in an HSA from taxable income, provided that it is coupled with a high deductible health plan. ${ }^{66}$

Are these products the elixir market advocates have been looking for? Judged against the prerequisites for effective health market competition discussed above - alleviating market failure and reducing fragmentationCDHC plans are ill-equipped to counter the deeply embedded problems in health care delivery that have frustrated competition in the past.

Examined through the lens of experience, the competition-improving narrative that $\mathrm{CDHC}$ proponents have advanced is seriously flawed.$^{67}$ Many Americans have had the experience of "directing" their own health care, shopping for health care services and insurance without assistance from third parties. The results are certainly not encouraging. For example, uninsured consumers, who encounter the market for health services on a regular basis, face enormous difficulties in obtaining care at reasonable costs and are forced to accept onerous conditions and terms.$^{68}$ Individuals forced to negotiate with providers who contract at discounted rates with insurers also face rampant price discrimination. As Hall and Schneider characterize the market dynamic, "uninsured patients must 'bargain' individually with providers who are

65. See Paul Fronstin \& Sara R. Collins, The 2nd Annual EBRI/Commonwealth Fund Consumerism in Health Survey 2006: Early Experience with High-Deductible and Consumer-Driven Plans (Employee Benefit Research Institute, Washington D.C.) (Dec. 2006), http://www.ebri.org/publications/ib/ index.cfm?fa=ibDisp\&content_id=3769. See generally Wendy K. Mariner, Can Consumer-Choice Plans Satisfy Patients? Problems with Theory and Practice in Health Insurance Contracts, 69 BROOK. L. REV. 485 (2004) (describing consumer-driven plans and arguing that they effectively ask patients to ration their own care) [hereinafter Can Consumer-Choice Plans Satisfy Patients?]. See also Gary Claxton et al., Health Benefits in 2006: Premium Increases Moderate, Enrollment in Consumer-Directed Health Plans Remains Modest, 25 Health AfF. WeB EXClusive w476 (Sept. 26, 2006), http://content.healthaffairs.org/cgi/ reprint/25/6/w476.pdf.

66. See Rev. Rul. 2002-41, 2002-2 I.R.B. 75 (stating employer's contribution to HAS is not taxable if funds are used to pay certain medical expenses); Timothy S. Jost \& Mark A. Hall, The Role of State Regulation in Consumer-Driven Health Care, 31 AM. J.L. \& MED. 395 (2005); see also Melinda Beeuwkes Buntin et al., Consumer-Directed Health Care: Early Evidence About Effects on Cost and Quality, 25 HeAlth AfF. Web EXClusive w516, w518 (2006), http://content.healthaffairs.org/cgi/reprint/ 25/6/w516.pdf.

67. See Jost \& Hall, supra note 66.

68. See Mark A. Hall \& Carl E. Schneider, Patients as Consumers: Courts, Contracts, and the New Medical Marketplace, 106 MiCH. L. REV. 643, 645 (2008) (analyzing structure and outcome of health care markets for uninsured consumers and concluding, "[t]he market for uninsured medical services is a calamity"). 
determined to recoup what they bargained away to insurers." ${ }^{69}$ In addition, some basic necessities for effective shopping are missing: prices for health services are not readily available, or knowable, ex ante. ${ }^{70}$ Likewise those left to buy health insurance in the individual market have encountered significant problems in comparing offerings and understanding risks associated with copayment obligations and limitations on coverage. ${ }^{71}$

Stepping back to look at the design of consumer driven plans, CDHC does little to counteract market failures other than moral hazard. Problems of agency, information deficits, and monopoly power in provider markets are left unchecked, and perhaps worsened, under a disintermediated insurance market. ${ }^{72}$ Consumer directed solutions may assume that consumer bargaining can create marketplace pressures that would encourage providers to assemble into efficient delivery organizations. But absent some mechanism for removing the impediments to effective consumerism-i.e. addressing welldocumented problems of obtaining and interpreting information and dealing with misaligned incentives associated with provider agency ${ }^{73}$ - there is no basis to assume the market will drive providers to reorganize into more efficient delivery systems.

Will CDHC plans develop tools to counter fragmentation? Consider two contractual measures that rely on market incentives. One widely employed demand-side incentive is "tiering." Designed to incentivize consumers to make value-focused choices, these provisions offer reduced cost sharing to beneficiaries who choose selected providers. Providers are classified in tiers, typically based on financial factors such as fees and utilization patterns. Consumers are thus provided a signal regarding the cost of their care (the differentials in cost sharing obligation) and may incorporate that factor in choosing among providers. A related strategy that operates on the supply side, "pay for performance," rewards providers with higher reimbursement if they achieve specified cost and quality goals. Both of these approaches are even

69. See id. ("Insurers aggressively negotiate rates for plan members; uninsured patients must 'bargain' individually with providers who are determined to recoup what they bargained away to insurers.").

70. See Paul B. Ginsburg, Shopping for Price in Medical Care, 26 Health Aff. Web Exclusive w208 (2007), http://content.healthaffairs.org/cgi/reprint/26/2/w208.pdf. Individuals forced to negotiate prices with providers who contract at discounts with insurers face rampant price discrimination.

71. See Judith H. Hibbard et al., Is the Informed-Choice Policy Approach Appropriate for Medicare Beneficiaries?, 20 HeAlth AfF. 199 (2001); Eric Johnson et al., Framing Probability Distortions, and Insurance Decisions, 7 J. RISK \& UNCERTAINTY 35 (1993).

72. See Bryan E. Dowd, Coordinated Agency Versus Autonomous Consumers in Health Care Markets, 24 HeALTH AfF. 1501 (2006).

73. See Jost, supra note 64 , at $408-11$. 
more vulnerable to the problems of market failure and fragmentation than the managed care methods that preceded them. Autonomous consumers face intractable problems of assembling accurate comparative information to make comparison among tiers and will still be subject to the compelling influence of their physician agents who recommend treatments and suggest referrals. With the bulk of the most costly care ordered by physicians, but provided by others, and many conditions requiring multiple caregivers, it is often impossible to accurately target rewards (or penalties based on performance) in the absence of integrated systems. ${ }^{74}$ Casting further doubt on the efficacy of these tools is the fact that the payment system rewards some less beneficial services (usually procedures and tests) more than others (such as cognitive services). This underpayment for efficacious alternatives obviously makes it hard to induce integrated practices that reduce lucrative services. In these instances, the integrated practice that "does the right thing," and in fact reduces costs, may lower overall profits even when it is rewarded for its cost saving reductions. ${ }^{75}$ Further, research suggests that payors that account for only a small fraction of their contracting physicians' patients may face difficulties in inducing physicians to change their practice style. ${ }^{76}$

Finally, even if these cost containment strategies are widely adopted, they may ultimately prove insufficient given the design of CDHC plans. The incentives of consumer directed plans are most likely to be effective with regard to routine care. For high-cost services, especially those occurring under emergent circumstances, financial incentives will have less impact, and in any event, CDHC plans offer full catastrophic coverage. Further, fee-for-service reimbursement, which is employed in CDHC plans, focuses on episodes of care rather than treating chronic conditions or encouraging prevention, and thus operates at cross purposes with the cost containment strategies. More fundamentally, the vision of the competitive market constructed by CDHC tends to undermine risk pooling and shift financial burdens from the healthy

74. See Michael F. Cannon, Pay-for-Performance: Is Medicare a Good Candidate?, 7 YALE J. Health Pol. L. \& Ethics 1 (2007); James C. Robinson, Managed Consumerism in Health Care, 24 HEALTH AFF. 1478 (2005).

75. For an instructive example of the difficulties of constructing payment systems that reward high performing providers, see Hoangmai H. Pham et al., Redesigning Care Delivery in Response to a HighPerformance Network: The Virginia Mason Medical Center, Health Aff. Web ExClusive w532 (2007), http://content.healthaffairs.org/cgi/reprint/26/4/w532.pdf; Paul B. Ginsburg \& Joy M. Grossman, When the Price Isn 't Right: How Inadvertent Payment Incentives Drive Medical Care, HEALTH AfF. WeB EXCLuSIVE (Aug. 9, 2005), http://content.healthaffairs.org/cgi/reprint/hlthaff.w5.376v1.

76. See Sherry Glied \& Joshua Graff Zivlin, How Do Physicians Behave When Some (But Not All) Their Patients Are in Managed Care?, 21 J. HEALTH ECON. 337 (2002). 
to the sick and from the privileged to underprivileged. ${ }^{77}$ Ultimately, the "logic" of the CDHC market, which seems inexorable to proponents, may not withstand political scrutiny, and a "CDHC backlash" seems likely to follow.

\section{CONCLUSION}

Viewed from the Panglossian perspective of some market theorists, competition inexorably drives suppliers to form firms or joint ventures and to adopt organizational forms that enable them to provide their services efficiently. But in health care, we have learned that market failure complicates things enormously. Agency issues, information deficits, and moral hazard alter incentives and interfere with rational choice. Managed care once seemed capable of helping to overcome those difficulties, and competition policy sought, sometimes quite explicitly, to aid that enterprise. For a variety of reasons antitrust came up short, and managed care fell into disfavor. The lesson for policymakers and law enforcers is that the success of a competitive strategy in health care is highly contingent. Supportive measures in law and financing are required to create an infrastructure that counters market failure and incentivizes the private sector to glue together its fragmented elements.

77. James C. Robinson, Managed Consumerism in Health Care, 24 HeALth AFF. 1478, 1483 (2005). 